\title{
INTERNATIONAL TRADE AND UNEVEN DISTRIBUTION OF INCOME
}

\author{
David Nersik Hakhverdyan \\ Professor at the Chair of "International Economic Relations", \\ Doctor of Sciences, \\ Armenian State University of Economics \\ 128 Nalbandyan str., 0025 Yerevan, Republic of Armenia \\ e-mail:dhakhverdyan@yahoo.com; ORCID:https://orcid.org/0000-0002-4592-3226 \\ Anna Armen Pakhlyan \\ Lecturer at the Chair of "International Economic Relations", \\ PhD in Economics, \\ Armenian State University of Economics \\ 128 Nalbandyan str., 0025 Yerevan, Republic of Armenia \\ e-mail:anna.pakhlyan@gmail.com; ORCID:https://orcid.org/0000-0002-5854-2473
}

\begin{abstract}
The turbulent events of the last quarter of the 20th century (the collapse of the socialist system and the transition of the post-socialist countries to a market economy, China's accession to the world market and the successive trends of trade liberalization in a number of countries) do not doubt that trade and technology play an important role in changing the structure of production and wages throughout the world.

At the beginning of the 20th century globalization tendencies were transformed into a deglobalization. This was partially due to the fact that growth of international trade did not properly contribute to the welfare of people and the mitigation of income polarization as it was expected to. Although, there is no doubt that trade and technology have played an important role in the change of production structure and salaries around the world.

The subject of research in the article are the main causes and consequences of the polarization of income in the world economy. The purpose of the study is to identify the impact of the growth of international trade on human well-being and reduction of income polarization. The main objective of the study is to analyze the dynamics of income distribution in the world in the context of the expansion of international trade.

The article uses general scientific methods: system analysis - to determine the features of the development of international trade, a method of scientific abstraction that allows to present the general nature of the uneven distribution of income in the world economy and to make assumptions about the expected future through extrapolating data.

Results: Based on the analysis of the dynamics of the change in the basic indicators of income distribution, the problem aspects of the impact of international trade on the polarization of the world population's incomes are revealed.Conclusion:According to studies,economic growth rates deepened inequality between countries, as some have learned to benefit from new opportunities better than others. Moreover, it turned out that trade is affecting the labor market disproportionately even within one country.

Key words: international trade, globalizationtrade, liberalization, income, poverty, income polarization, inequality in labor remuneration, premiums for qualifications.
\end{abstract}

It is assumed that decades following the Cold War are considered to be globalization times. Trade and commerce rates have steadily increased among countries. Since the collapse of the Berlin Wall in 1989 up to the first signs of the global financial-economic crisis in 2007 international trade flows increased from $39 \%$ to $59 \%$ of global GDP [1].

But the picture is not like that today. The trade is stagnant. Is this all evidence of the new, perhaps the beginning of the era of Deglobalization? We can not rule out such a turn of events: Globalization tendencies of the end of the 19th century were transformed into a deglobalization at the beginning of the 20th century. Nevertheless, in the absence of shock (World War I or the Great Depression of the 1930s), the history will hardly be repeated. It can be concluded, that globalization is changing, and not remaining stagnant or turning around [1].

In this context, another question is of great importance. To what extent the growth of international trade contributes to the welfare of people and the mitigation of income polarization? The stormy events of the last quarter of the era leave no doubt that trade and technology have played an important role in the change of production structure and salaries around the world. In the beginning of 1990s, a number of circumstances changed the world economy. The socialist system collapsed, allowing post-socialist countries to switch to a market economy that was open to international trade and investment.

Approximately in this period, China, which began the process of market formation in 1978, accelerated it, particularly by allowing many companies to engage in commercial activities and reducing export and import barriers. Other developing countries, including Latin America and India (where large-scale reforms were implemented in 1991), also opened to trade, seeking to overcome the consequences of slow, prolonged growth of nearly a decade. In addition, in many cases the level of openness for FDI and other forms of financial flows has increased, which has been an additional stimulus for export.

With time, these phenomena were not in vain to be accepted with great enthusiasm. They led to the formation of the global trading system that did not have a precedent in its history. Not only did it provide 
economic (and in some cases political) liberties for billions of people all over the world, but also more intensive growth as a result of increasing revenue, consumption, investment and innovation in the world. In many emerging markets, economic growth rates have accelerated, which deepened in-country inequality, as some have learned to benefit from new opportunities better than others. In such countries as India and China, for the first time a huge middle class was formed. It was during this period that the major implications of global change became noticeable, especially for workers in the developed countries, who faced a dramatic increase in the global supply of labor force (especially low-skilled). As of 2000, China, India and the post-Soviet countries gave around 1.5 billion employees to the global economy, thus doubling its labor resources [2].

According to Stopler-Samuelson conclusion, the global growth of labor force and capital ratio in developed countries reduces labor remuneration compared to capital incomes, and due to this is probably explained a slight increase in average wages and reduction of labor force share in GDP in North America, Western Europe and Japan. This process was accelerated by decline in the role of trade unions, as well as the widespread actions of transnational corporations transferring production to countries with low labor costs. Stopler-Samuelson scheme also suggests that in poorer countries the wage rate of lowskilled workers is growing, whereas in wealthy countries, highly qualified workers are winning, that is, the inequality in labor remuneration reduces in poorer countries and increases in wealthier ones. Nevertheless, after the 1980s the gap between qualified and unskilled workers' wages increased in both countries. The fact that the premiums for qualifications grew even within individual sectors, but and there was no reduction in the share of employment of a low-skilled labor force in developed countries as a result of a decrease in their relative value, also contradicted the StolperSamuelson theory.

Many economists believe [3] that in the 1990s, the overall increase in qualification bonuses is mainly explained by technological changes (e.g. changes in the IT sphere, other global changes), from which highly qualified workers have gained. However, it is not ruled out that trade expanding has also played a role in this, as it became clear that exporting firms from different sectors usually involve relatively skilled workforce than non-exporting companies, so trade growth could have driven the demand for qualified labor force. Among the likely factors is the transfer of work on the basis of the relevant agreement: non high-skilled workplace movements from richer to relatively poor countries can contribute to the overall growth of qualification bonuses [4]. Trade benefits usually exist if countries specialize in specific areas, and trade leads to redistribution of workforce from industries competing with imports to export-oriented sectors. This leads to the reduction of earnings of workers in sectors competing with imports and to the increase in employees' earnings in export-oriented industries, at least in the short term. Disadvantageous impact of trade on income is also observed in other cases.

International trade can lead to the inequality of employees' income from different companies of the same branch. The companies differ by efficiency, and those showing the best results have greater opportunities to enter the export markets. Research conducted in Argentina and Mexico showed that leading companies use new export opportunities and "share" with employees with additional income, raising their salaries [5].

Besides, qualified employees of companies exporting to high-income countries, in contrast to less educated employees, receive additional surplus earnings. How is this explained? Consumers of countries with high incomes, unlike consumers in emerging markets, often demand higher quality goods. The production and consumption of high quality products, in turn, require skills of more qualified employees or more efforts, and thus, the gap between the two groups of employees increases within the company.

It's important to note that, according to several studies, trade is affecting the labor market disproportionately even within one country.

Vietnam is an outstanding example. According to the trade agreement 2001, the export taxes of the Vietnamese companies' exports to US were reduced on average by 23 percentage points. At the same time, tax reduction significantly differed between branches. The provinces of Vietnam are specialized in different fields, and employment in some provinces has been concentrated in those sectors where taxes have been reduced and the number of workers in similar branches in other regions is very small. As a result, the reduction of export expenditures has affected the state of the various provinces in a different way.

One study has shown that poverty has more dwindled in the provinces where the sectors' export costs have largely decreased [6]. The poverty was diminished because the US market accession increased the demand for local labor force and raised wages in the provinces, especially for those workers whose educational level did not exceed the primary level. Significantly benefited provinces were initially rich, that is why with the increase in trade volumes accrued also the regional disparities in labor rewards.

Research on Vietnam suggests that international trade creates disruptions between income levels of the country regions. Some regions are exposed to the influence of international trade more than the others, which is conditioned by their production specialization. 
Let's look at India's example where lived about 1/3 of the world's poorest population when in 1991 the country went through trade liberalization. This reform has reduced the quantitative restrictions on trade and, in 1996, reduced the import customs duties on average from $87 \%$ to $37 \%$. P.Topalova analyzed the impact of customs duties on imports in various parts of India, which raised foreign competition [7].

In India, poverty at the national level has declined during that period. Nevertheless, the survey showed that poverty decreased less in those agricultural sectors of India, where import competition was much higher. Relative poverty has risen as customs duties decline have diminished the demand for local labor, which led to a reduction in industrial and agricultural labor remuneration and disproportionately deteriorated the state of poor families. Finally, the relative reduction in per capita consumption was the most considerable in families with a minimum income of 10 and 20 percent.

It turns out that the results of competition with imports for local labor markets can be preserved and deteriorated over time [8, 9]. The recent study examines the adaptation process for workers over two decades following the reduction of import customs duties in Brazil at the beginning of 1990s [10]. Like in India, this reform has reduced the income of workers in the regions as a result of increased competition with imports. However, in contrast to India, inequalities in Brazil's regions reduced, as the regions affected by the reform were originally quite rich. Inequities in incomes may be quite profound, as labor force and capital can not move freely, and redistribution between regions is not so intense (especially in developing countries). As a result, the consequences of international trade fluctuate for workers, depending on how it affects the local economy [11].

Although over the past decades income inequalities declined between countries, inequality has grown in many, especially in richer countries. Trade and technology development has accelerated global rapprochement (leveling) of income for most of the people in the poorer countries by changing production structure and redistributing revenues inside the country. There are some striking examples of disparities between countries that can be found in Asia, in this case it should be mentioned that Hong Kong, Singapore, Korea, Taiwan, and China transitioned to a group of high-income countries, as well as the recent economic growth of India and China. In India, the real GDP per capita in 1991 was 553 US dollars, and in 2015, it was 1806 USD. The same indicator in China was 783 US dollars in 1991, and 6416 US dollars in 2015. Taking into account the large population of India and China, their success has contributed to a significant reduction in inequalities in the world's population. African countries situated south from Latin America and
Sahara, where the growth rates are relatively slow, did not reduce rapidly their fracture with developed countries, but in less-favorable countries poverty has dropped dramatically [3].

These successes in reducing income and poverty are often conditioned by international trade and investment, moreover, in most cases not due to free trade policy, but due to external orientation of production.

However, the gains of this growth are not always equally distributed between developing and developed countries. In general, inequality has grown in Asia and Eastern Europe, whereas in some Latin American countries (the most obvious example is Brazil), it has dropped, though it still remains high throughout the world. Deepening inequality in almost all developed countries, along with the slowdown in economic growth, has led to a reduction in long-term growth in household income, with the exception of the upper segment (see Figure 1).

The reasons for such a downturn are complicated, but are partially linked to the global financialeconomic crisis.

The US example serves as a reflection of how economic growth in developed economies, along with the slowdown in the post-war era, have gradually become less inclusive ${ }^{1}$. According to the data of US Census Bureau, the average annual income of the family in 2014 amounted to $\$ 53,657$, which in real terms (taking into account the inflation) corresponds to the indicator of 1989. For comparison, let's mention that in 19501980, this figure of income has almost doubled. In the last quarter of the era, after a period of active economic progress, the data of which was accessible to the majority of the population, almost half of the US families were deprived of this opportunity (this continued until 2015, when the average income grew sharply by $5.2 \%$ [3].

These events largely reflect the peculiarities of the country's development, such as progressive taxation changes, managers' premiums or economy funding restrictions. Nevertheless, globalization and technical progress are unique motive forces. Technical innovations, such as telecommunication technologies, have enabled expanding trade scales in areas such as banking services and insurance. Getting access to export markets or being subjected to competitive pressure by importers companies can improve their manufacturing processes through innovations. FDI, as well as trade, can lead to the exchange of advanced technologies among countries, which affects the peculiarities of comparative advantages. In other words, globalized trade promotes technologies to turn into global factors [3]. As shown by B. Milanovitch, this tendency resulted in considerable benefits for the middle class of the Third World countries and $1 \%$ of the 
richest people in the world generally, while the picture for the lower class of developed countries is rather irreparable. From the point of view of global prosperity it is undoubtedly a positive phenomenon: increasing the income of millions of past poor people has a great significance, but for a low-income world, it's hardly a solace.

In the light of this reality, it is even strange that negative attitude towards globalization expressed so late, and its consequences are still not so great. Many predicted turning back to protectionism after the crisis of 2008-2010, but obvious trade restrictions are still not noticeable.
It must be admitted that the more liberal trade and investment activity movement has probably stopped. Moreover, it even began to slow down until the global economic crisis [12].

Of course, the global trade war, which would have negative consequences for the poorest countries exporting labour intensive goods, is a rather different matter. However, if it is achievable to avoid such a failure, it is possible that the best option is to accept globalization as a more or less complete process and to reduce the debate over this issue.

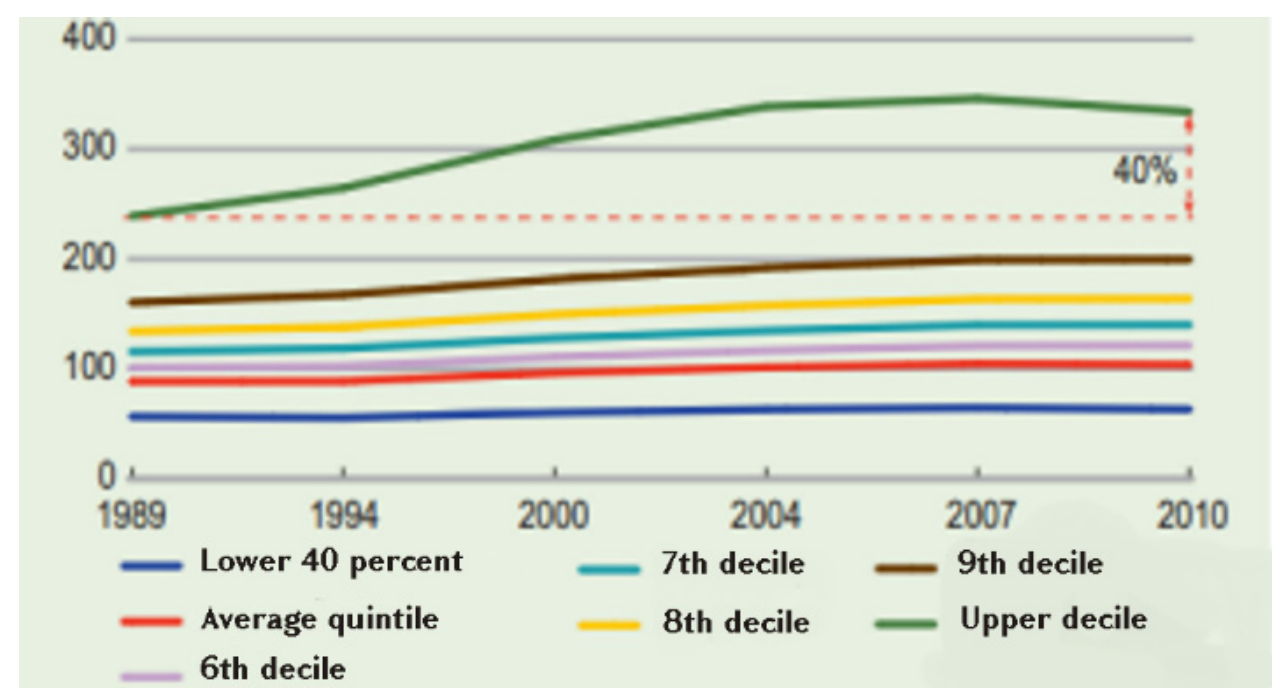

Figure 1. Household Income Dynamics in Developed Countries (Million USD) ${ }^{2}$

\section{МІЖНАРОДНА ТОРГІВЛЯ ТА НЕРІВНОМІРНИЙ РОЗПОДІЛ ДОХОДІВ}

Ахвердян Давид Нерсікович, Доктор економічних наук, Професор кафедри «Міжнародні економічні відносини», Вірменський державний економічний університет, 128 Налбандян, 0025 Єреван, Республіка Вipменія, e-mail:dhakhverdyan@yahoo.com; ORCID: https://orcid.org/0000-0002-4592-3226

Пахлян Анна Арменівна, Викладач кафедри «Міжнародні економічні відносини», Кандидат економічних наук, Вірменський державний економічний університет, 128 Налбандян, 0025 Єреван, Республіка Вipменія, e-mail:anna.pakhlyan@gmail.com; ORCID: https://orcid.org/0000-0002-5854-2473

Бурхливі події останньої чверті XX століття (крах соціалістичної системи і перехід постсоціалістичних країн до ринкової економіки, вихід Китаю на світовий ринок і послідовні тенденції лібералізації торгівлі в ряді країн) не викликає сумнівів в тому, що торгівля і технології відіграють важливу роль у зміні структури виробництва і заробітної плати в усьому світі.

На початку XX століття тенденції глобалізації трансформувалися в деглобалізації. Це було частково пов'язано з тим, що зростання міжнародної торгівлі належним чином не сприяло добробуту людей і зменшення поляризації доходів, як раніше очікувалося. Хоча, безсумнівно, торгівля і технології зіграли важливу роль у зміні структури виробництва і заробітної плати в усьому світі.

Предметом дослідження в статті є основні причини та наслідки поляризації доходів в світовій економіці. Метою дослідження $€$ виявлення обсягів впливу зростання міжнародної торгівлі на добробут людей і зменшення поляризації доходів. Основним завданням дослідження $€$ аналіз динаміки розподілу доходів в світі в умовах експансії міжнародної торгівлі.

У статті використовуються загальнонаукові методи: системний аналіз - для визначення особливостей розвитку міжнародної торгівлі, метод наукової абстракції, що дозволяє зробити загальний характер нерівномірного розподілу доходів в світовій економіці і робити припущення про очікуване майбутньому шляхом екстраполяції даних.

Результати: На основі проведеного аналізу динаміки зміни основних показників розподілу доходів виявлено проблемні аспекти впливу міжнародної торгівлі на поляризації доходів населення світу. Висновки: Згідно з дослідженнями, темпи економічного зростання поглибили нерівність між країнами, оскільки деякі з них навчилися краще використовувати нові можливості, ніж інші. Більш того, виявилося, що торгівля впливає на ринок праці непропорційно навіть всередині однієї країни.

Ключові слова: міжнародна торгівля, глобалізація, лібералізація торгівлі, доходи, бідність, поляризація доходів, нерівність в оплаті праці, премії за кваліфікацію.

\footnotetext{
${ }^{2}$ In the last 25 years, the income of the top $10 \%$ population of the developed countries has steadily increased, while the income growth of middle
} class and poorer layers was not adequate. Source: Luxembourg Center for

Income Research, based on Revenue Distribution (New York Times (2014) and IMF calculations. 


\section{МЕЖДУНАРОДНАЯ ТОРГОВЛЯ И НЕРАВНОМЕРНОЕ РАСПРЕДЕЛЕНИЕ ДОХОДОВ}

Ахвердян Давид Нерсикович, Доктор экономических наук, Профессор кафедры «Международные экономические отношения», Армянский государственный экономический университет, 128 Налбандян, 0025 Ереван, Республика Apмeния, e-mail: dhakhverdyan@yahoo.com; ORCID: https://orcid.org/0000-0002-4592-3226

Пахлян Анна Арменовна, Преподаватель кафедры «Международные экономические отношения», Кандидат экономических наук, Армянский государственный экономический университет, 128 Налбандян, 0025 Ереван, Республика Армения e-mail: anna.pakhlyan@gmail.com; ORCID: https://orcid.org/0000-0002-5854-2473

Бурные события последней четверти XX века (крах социалистической системы и переход постсоциалистических стран к рыночной экономике, выход Китая на мировой рынок и последовательные тенденции либерализации торговли в ряде стран) не вызывает сомнений в том, что торговля и технологии играют важную роль в изменении структуры производства и заработной платы во всем мире.

В начале XX века тенденции глобализации трансформировались в деглобализацию. Это было частично связано с тем, что рост международной торговли надлежащим образом не способствовало благосостоянию людей и уменьшению поляризации доходов, как ранее ожидалось. Хотя, несомненно, торговля и технологии сыграли важную роль в изменении структуры производства и заработной платы во всем мире.

Предметом исследования в статье являются основные причины и последствия поляризации доходов в мировой экономике. Целью исследования является выявление объемов воздействия роста международной торговли на благосостояние людей и уменьшение поляризации доходов. Основной задачей исследования является анализ динамики распределения доходов в мире в условиях экспансии международной торговли.

В статье используются общенаучные методы: системный анализ - для определения особенностей развития международной торговли, метод научной абстракции, что позволяет представить общий характер неравномерного распределения доходов в мировой экономике и строить предположения об ожидаемом будущем путем экстраполяции данных.

Результаты: На основе проведенного анализа динамики изменения основных показателей распределения доходов выявлены проблемные аспекты воздействия международной торговли на поляризации доходов мирового населения. Выводы: Согласно исследованиям, темпы экономического роста углубили неравенство между странами, поскольку некоторые из них научились лучше использовать новые возможности, чем другие. Более того, оказалось, что торговля влияет на рынок труда непропорционально даже внутри одной страны.

Ключевые слова: международная торговля, глобализация, либерализация торговли, доходы, бедность, поляризация доходов, неравенство в оплате труда, премии за квалификацию.

\section{References}

1. Маллаби С. Перезагрузка глобализации // Финансы и развитие: ежеквартальный журнал Международного Валютного Фонда - 2016 - Выпуск 53. - Номер 4. - С. 7.

2. Freeman Richard B. The Great Doubling: The Challenge of the New Global Labor Market, 2007, in Ending Poverty in America: How to Restore the American Dream, ed. by John Edwards, Marion Crain, and Arne L. Kalleberg (New York: New Press).

3. Обстфельд М. Возвращение на путь свободной торговли // Финансы и развитие: ежеквартальный журнал Международного Валютного Фонда - 2016. - Выпуск 53. - Номер 4. - С. 14-15.

4. Feenstra Robert C., Gordon H. Hanson 1996 Globalization, Outsourcing, and Wage Inequality // American Economic Review, Vol. 86. - 1996. - No. 2. - pp. 240-245.

5. Verhoogen Eric. Trade, Quality Upgrading, and Wage Inequality in the Mexican Manufacturing Sector," Quarterly Journal of Economics, Vol. 123. - 2008. - No. 2. - pp. 489-530; Brambilla, Irene, Daniel Lederman, and Guido Porto, 2012, "Exports, Export Destinations, and Skills," American Economic Review, Vol. 102. - No. 7. - pp. $34-38$.

6. Brian Mc Caig. Exporting out of Poverty: Provincial Poverty in Vietnam and U.S. Market Access // Journal of International Economics, Vol. 85. - 2011. - No. 1. - pp. 102-13.

7. Topalova Petia. Factor Immobility and Regional Impacts of Trade Liberalization: Evidence on Poverty from India // American Economic Journal: Applied Economics, Vol. 2. - 2010. - No. 4. - pp. 1 - 41.

8. Babenko V., Sidorov V., Savin R. Activities of international agroholdings in the world market of foreign investments: investigation of trends and factors of impact in current financing conditions // Technology audit and production reserves. - Vol. 4, No 4 (42), 2018. - P. 18-24. DOI: https://doi.org/10.15587/2312-8372.2018.141135

9. Dix-Carneiro Rafael, Brian Kovak, 2015, Trade Liberalization and Regional Dynamics, unpublished (Durham, North Carolina: Duke University).

10. Бабенко В.О., Сідоров В.І., Фірсанова В.О., Бондаренко М.І. Аослідження розвитку інтеграційних процесів у глобальній системі міжнародної торгівлі // «Вісник соціально-економічних досліджень» Одеського національного економічного університету, 2018. - № 1 (65). - С. 36-48.

11. Павчник Н. В богатстве и в бедности // Финансы и развитие: ежеквартальный журнал Международного Валютного Фонда - 2016 - Выпуск 53. - Номер 4. - С. 34-35.

12. Кругман П. Не будите зомби // Финансы и развитие: ежеквартальный журнал Международного Валютного Фонда - 2016 - Выпуск 53. - Номер 4. - С. 11. 